\title{
Quem quer ser milionário? Quem quer ser professor? Narrativas e perspectivas que instigam reflexões sobre a docência
}

\author{
Who wants to be a millionaire? Who wants to be a teacher? Narratives \\ and perspectives that promote reflections about teacher career
}

\section{Nestor André Kaercher' ${ }^{10}$, Marcos Bohrer' ${ }^{(D)}$, Igor Armindo Rockenbach' ${ }^{(D)}$}

' Universidade Federal do Rio Grande do Sul , Programa de Pós-Graduação em Geografia, RS, Brasil

\section{RESUMO}

O presente artigo objetiva refletir acerca da atratividade da carreira docente junto à juventude, bem como analisar possíveis cenários para o futuro da educação básica. Para isso, abordam-se relatos e narrativas de cinco diferentes licenciados em Geografia: um recém-egresso; três formandos e um profissional já formado. De que maneira as opções (ou a falta delas) levam uma pessoa a torna-se professor refletem na escola, na cidadania e na própria democracia no Brasil? Como resultados, analisase que em dois casos, apesar da idade semelhante (cerca de 30 anos), os docentes apresentam origens sociais distintas que produzem impactos nas suas trajetórias profissionais. Sinaliza-se que buscar a felicidade no exercício da profissão é uma utopia e uma necessidade e que educar as novas gerações com profissionais desestimulados e/ou infelizes poderá trazer consequências consideráveis para o país.

Palavras-chave: Escolha profissional; Formação de professores; Felicidade; Ensino de Geografia

\section{ABSTRACT}

This article paper wants to reflect on the attractiveness of the teaching career among youth and suggest possible scenarios in the future of basic education. It presents the situations of five different Geography teachers: a recent graduate; three almost graduated and one professional already formed. What consequence the options (or lack of them) to choose the teacher's career brings to school, citizenship and democracy in Brazil? As a result, there are an analysis of two cases were the professionals, despite their similar age (around 30 years), have different social origins that impact their professional trajectories. The text considers that seeking happiness in the exercise of the profession is a utopia and a necessity and educating new generations by discouraged and/or unhappy professionals will have big consequences for the country. 
Keywords: Professional choice; Teacher training; Happiness; Geography teaching

\section{INTRODUÇÃO}

Nada sei fazer que não seja, mal ou bem, escrever o que sinto. Não sei mudar o mundo nem contribuir para grandes projeções. Só me resta expressar minha perplexidade diante das misérias que se perpetuam dos nossos olhos tristes. (SILVA, 2020a)

Este texto pretende relatar algumas situações reais vividas pelos autores na sua trajetória profissional como professores formadores de professores e professoras. Mais do que conclusões (essas tão solicitadas em textos acadêmicos) ou conselhos (esses tão comumente dados por professores/as aos alunos/as, sejam eles/elas de quaisquer idades) queremos propiciar ao leitor/a um possível quadro dos dilemas profissionais (e existenciais) da juventude brasileira que realiza o curso de licenciatura nos tempos atuais. Não objetivamos generalizar ou prescrever teses, mas nos permitiremos fazer associações entre os casos individuais listados aqui com o contexto social maior de nosso país, sem delinear um dossiê acerca do que leva um/a jovem a optar pela licenciatura. Mas entender o que foi posto por eles, alunos/as da universidade ou professores/as em ação. Temos como intuito refletir acerca do futuro profissional destes/as, sem a pretensão de ser porta-voz dos mesmos, claro. Sou professor/a (formado/a), e agora? Para fazermos uma pergunta geográfica e existencial: onde fui/vou me meter com este curso? Onde - e como - vou ter uma vida digna como profissional da educação básica? O tema da felicidade é pertinente na discussão da formação de professores/as?

Os casos relatados na sequência estão escritos no singular, pois são casos coletados pelos autores em seus distintos locais de trabalho. É indiferente o local, o docente, o município e o/a aluno/a. O que importa, para nós formadores de professores e professoras, é o relato. 


\section{POSSIBILIDADES E PERSPECTIVAS NA ESCOLHA PELA DOCÊNCIA}

\subsection{Caso um}

E eu acabara de aprender que a vida tem de ser mais à deriva, mais ao acaso, porque quem se guarda de tudo foge de tudo. (MÃE, 2018, p. 312)

Um jovem aluno (24 anos) conversa comigo ${ }^{1}$ sobre o seu Trabalho de Conclusão de Curso (TCC). Ele já havia concluído os estágios de Licenciatura e estava para concluir o curso no final do semestre (2020/1). É um aluno muito bom. Curioso, criativo e muito comunicativo. Poucas dúvidas de que será um excelente professor.

Após alguns minutos de conversa focada no respectivo trabalho ele vem com uma espécie de granada cujo pino foi retirado: "Professor, assim que me formar não sei se faço logo outro curso ou vou tentar a vida na Itália". Fico meio surpreso, acho meio divagação. A coisa piora quando ele põe a granada - está sem o pino no meu colo: "Que tu achas, professor? Que curso tu achas que tem mais futuro? Que tu achas de tentar a sorte na Itália? Não 'tô' vendo muito futuro na docência!". As palavras da conversa não foram, talvez, exatamente estas, mas a ideia é esta mesma: o que fazer pós-formatura? Parece-lhe claro que ser professor/a não tem futuro. Aliás, ele me diz isso e eu tento desconversar, dizer que não é bem assim. Outro ponto: ele tem o passaporte italiano, ou seja, não seria um trabalho difícil adentrar na Europa. Entraria pela porta da frente.

Trocamos na ocasião - e outras vezes - muitas ideias sobre o presente e o futuro. É comum ele mostrar seu espanto com conversas e postagens de familiares dele não só na linha política, mas, o que lhe assusta mais, o negacionismo da ciência. A cada frase ou argumento "pessimista" dele procuro atenuar, contrapor, dizer que a sociedade é múltipla, há bons motivos para o pessimismo e para o otimismo. Sinto que tento, também, me convencer. Riso.

\footnotetext{
${ }^{1}$ Os diálogos dos dois primeiros casos são narrados por Nestor André Kaercher.
} 
O que me deixa pasmo é ver a sincera desilusão acerca das perspectivas profissionais de um jovem bem preparado que está concluindo o curso. Seu desempenho acadêmico é de qualidade. A angústia dele me é duplamente perturbadora. A lucidez de suas questões. A clareza em ver os cenários da educação e das escolas no Brasil. Vê com sobriedade o que é... sombrio. Relata os impasses gerados pelas políticas nacionais relativas à Educação no Plano Federal (como pibidiano viu a possível descontinuidade/enfraquecimento do Programa de Bolsa de Iniciação à Docência, o PIBID). Mais perturbador, no entanto, é o receio de eu não ter argumentos claros e contundentes em favor em dizer-Ihe que fique na profissão, que ela tem muito futuro, que as perspectivas são grandes para a educação e as escolas brasileiras.

Este jovem, com certeza, se sair da docência, fará falta, pois tem uma visão de educar que ultrapassa em muito a mera técnica científica ou a informação atualizada. Vê-se que é pessoa sensível, politizada (sem querer ser um militante arrogante com certeza de tudo) e democrática. Há de se concordar com Silva (2020a):

Quando a noite cai, talvez pelos mistérios da falta de luz ou por sentir medo do escuro, eu penso nos vulneráveis que habitam a nossa cidade. De onde me vem esta preocupação lancinante com os que sofrem ou correm riscos que me assustam? Não sou herói nem virtuoso. Nada tenho de especial. Por que então estremeço ao sentir na pele o frio que se adensa e o vento que sacode os abrigos improvisados dos moradores de rua e os destinos do que já perderam quase tudo? Talvez eu tema me ver um dia como eles. Pode ser que, como quando eu era criança, ainda não entendia a existência de tanta pobreza num mundo que produz riquezas enormes, excessos, luxos e tanto desperdício. Fiquei velho sem compreender a chamada realidade com o seu cortejo de tristezas e maldades estruturais. 


\subsection{Caso dois}

O semestre (2020/1) transcorre com aulas remotas. As tarefas são entregues via e-mail. Um aluno (desta vez de $1^{\circ}$ semestre), portanto bem jovem (20 anos ou menos) e recém-saído do Ensino Médio manda o seguinte mail:

Eu vi em um gráfico (não sei se é atual, acho que sim) que o salário mensal dos professores em ensino estadual no RS é de R\$1.298 por mês. Aí eu não entendi, esse salário é só em relação a um período (tipo só de manhã, só de tarde...) ou em relação a dois períodos mesmo (manhã e tarde)? Isso me dá um medo, dedicar a minha vida a algo e talvez ganhar tão pouco..., mas talvez isso seja só uma interpretação errada minha do gráfico.

Respondo-Ihe no mesmo dia:

Prezado N. Por incrível que pareça isso corresponde a [aproximadamente] 20 horas, ou seja, 40 horas é o dobro. O RS é um dos estados que pior paga, tanto é que para chegar no Piso Nacional é preciso a figura do completivo, que é um acréscimo que o Estado faz para se chegar ao Piso Mínimo. O Estado está neste nível acintoso há anos. E ainda paga parcelado. Terrível. ${ }^{2}$

Nem Ihe expliquei que há milhares de educadores que há anos são contratados, isto é, por não serem concursados não tem estabilidade e não tem algumas "vantagens" que os concursados têm. Amorim, Salej e Barreiros (2018), em um estudo sobre a rede estadual de ensino em Minas Gerais, aponta o fenômeno da superdesignação, um grande número dos professores daquela realidade são designados, ou seja, possuem contratos temporários e gozam de menos direitos que os professores efetivos. Não entraremos em detalhes aqui, mas isso mostra uma precarização das condições de trabalho que atravessa outros estados do Brasil.

O que se teria, hoje então, seria uma rede de ensino ao avesso, com cerca de $30 \%$ de cargos de professor ocupados por docentes efetivos e

2 As informações relativas ao salário dos professores que instigaram essa discussão têm como fonte as Secretarias estaduais e sindicatos da categoria. Disponível em:

https://infograficos.gazetadopovo.com.br/educacao/piso-salarial-professor-no-brasil/. Acesso em 15 out. 2020. 
por aproximadamente $70 \%$ de cargos de professor tomados por docentes designados, quando o esperado seria quando muito o contrário. Eis aí o que se compreende por "superdesignação". (AMORIM; SALEJ; BARREIROS, 2018, p. 06)

Faço este pequeno adendo porque já não sei/sabemos quão intencional é a nossa estratégia de não falar de modo direto acerca da realidade da profissão docente. É uma atitude que já trazemos (ou ocultamos) há anos e é usada também quando nossos alunos estagiários se deparam com a realidade das escolas, seja do município, seja do estado. Creio que agimos intuitivamente: damos a informação conforme ela é solicitada. Não vamos além. Dizem que com criança/filho se age assim. Sabemos que eles não são nossos filhos, mas há um vínculo afetivo nessa relação.

Na sequência ele me mandou novo mail:

Então, por exemplo, se eu trabalhar de manhã e de tarde em uma escola estadual no RS, eu ganho R\$2.596, né? Eu sempre "bugo" quando as pessoas falam de $20 \mathrm{~h} / 40 \mathrm{~h}$, porque eu nunca sei se é em relação a que, por isso "tô" perguntando. Desculpe se eu estiver incomodando.

Em seguida, eu o respondo:

Não é incômodo, N. Acredito que seja (mais ou menos) este salário. Dentro desta carga horaria (20h ou 40h) você faz o horário em combinação com seu diretor(a). Infelizmente, quase todas estas horas são em sala de aula, ou seja, quase não há hora para preparação. Por ora, sugiro, não te preocupares muito com isso, seja porque quase todas as carreiras pagam mal, seja porque, se pensares só no dinheiro, poucas carreiras sobram. Traga este assunto para a nossa próxima aula, por favor. É importante.

Vejam que aí me contradigo. Ofereço-lhe uma informação preocupante (a quase totalidade das horas em sala de aula). De outra parte, dou uma 'enrolada' no jovem dizendo-lhe que o pagamento insatisfatório é generalizado. Será que é isso que poderíamos chamar de Geografia Crítica? (humor terrível). Mas, falando sério, este $2^{\circ}$ caso, vai ao encontro do $1^{\circ}$. Mostra mais um jovem (este também bem participativo e interessado em ser professor como já demonstrou em outro 
trabalho entregue) que, mesmo interessado e com potencial para ser um professor, se vê diante de obstáculos muito concretos: a baixa perspectiva de futuro na carreira.

Assim, refletimos: como nós, que formamos futuros professores, podemos conciliar o necessário entusiasmo que a profissão requer com o também necessário entendimento das condições concretas/cotidianas que ela será exercida na prática? Como denunciar as injustiças? Denunciar é preciso, mas se não mantermos um equilíbrio com o anúncio de possibilidades melhores, daremos aulas para as paredes. Como ir em direção do nosso mantra, já anunciado em outros textos que o professor pode pouco, mas este pouco não é nada desprezível. Nossa experiência coleta, todos os semestres, relatos de alunos que ingressam nas carreiras de Licenciatura motivados por exemplos de grandes professores da educação básica. Manter esta chama acessa é preciso, pois a profissão demanda muita energia, e, começar 'cansado/desanimado é inviável.

\subsection{Caso três}

Na continuidade do texto gostaríamos de agregar dois relatos do curso de Licenciatura em Geografia. Um já formado. Ambos com cerca de 30 anos, mas com experiências profissionais distintas. Fizemos ajustes no texto, encurtamos e alteramos algumas palavras e ou frases. Nada falseamos ou deturpamos.

Deixemos que falem os personagens de nossa história:

"UM POUCO DA MINHA HISTÓRIA

Meu nome é XXX. Nasci em 1992. A história que vou contar inicia em 1999. Nesse ano, eu e minha mãe nos mudamos do bairro Restinga e fomos morar no bairro Belém Velho, eu tinha sete anos. Na Restinga, moramos com o namorado da minha mãe, o R., gente fina. Moramos em uma casa muito boa, a melhor casa que já morei até hoje, tive bons momentos na Restinga, estudava na escola municipal. Mas, minha mãe e o namorado dela terminaram e por isso fomos morar no Belém Velho. A gente foi morar 
em um terreno alugado, cinquenta reais por mês, construímos uma "meia água" (casa com um banheiro e duas peças, normalmente quarto e cozinha), esta área onde alugamos o terreno, era um sítio ou algo do tipo e o dono resolveu fazer um loteamento (irregular, óbvio). Nem água encanada tinha, que dirá esgoto.

Eu continuei estudando na Restinga. la a pé da minha nova casa até o colégio. Minha mãe só dizia que eu tinha que estudar para ser alguém na vida e não passar as dificuldades que a gente passava, mas eu nem gostava de estudar! As coisas mais marcantes no colégio foram as oficinas de artes que eu fazia no turno inverso e os treinos de Handebol com a professora de Educação Física. Tinha um colega muito legal, o M. Ele era meu parceiro de recreio nos anos iniciais do ensino fundamental, lembro que eu sempre levava uma banana de lanche e ele levava bisnaguinha com queijo e salamito e dava pra mim. Na verdade, ele não gostava, trazia pra mim mesmo.

Já no bairro novo, como não tínhamos água encanada, tinha um mercadinho que deixava a gente buscar de balde a água para uso geral. Depois de um tempo (não sei precisar quanto, mas alguns meses), um homem que tinha uma oficina mecânica na rua, emprestou um galão de plástico de duzentos litros para não precisarmos fazer diversas viagens com os baldes, assim também, passamos a pegar água direto na oficina. Nessa nova morada fiz amigos, joguei bola na rua, tive carrinho de lomba, joguei taco, tive um amigo que, íamos nos campos ao redor e montávamos em cavalos. Quando a gente é criança, tudo é lindo. Logo depois meu irmão foi morar com a gente, fez um puxadinho pra ele e estava tudo certo. Lembro que a gente passou uns perrengues nessa época. Nossas refeições eram polenta, ovo, arroz e repolho cozido, minha mãe comprava uns ossinhos de porco, que vendem no açougue até hoje, daí dava uma encorpada na refeição. Isso me marcou porque foi um período grande que a gente comia isso. Lembro que roupa a gente recebia de doação ou quando minha mãe comprava era uns dois números maiores para durar mais. 
Nos anos finais do ensino fundamental, arrumei novos amigos. Meus dois melhores amigos passaram a ser o L. e o W. Como eu ia a pé para a escola, sempre passava na casa do W. antes para irmos juntos; o L. morava quase na frente da escola, então, quando a gente chegava, ele já estava lá. Nesse período eu segui jogando handebol, e, eventualmente, fazia oficina de artes. A minha relação dentro da sala de aula não foi tão marcante, mas uma coisa que eu carreguei foi a vergonha de perguntar em sala de aula e a dificuldade que eu tinha para entender o conteúdo quando chegava em casa. Minha mãe que estudou até a quinta série, também não sabia, me achava insuficiente. Ao mesmo tempo que ela fazia isso, ela também se achava insuficiente, simplesmente por também não conseguir me ajudar com os temas de casa

Aos treze anos eu passo a fazer capina nos pátios dos vizinhos (cortar/arrancar mato com enxada) para fazer um dinheiro. Nessas capinas conheci uma senhora que tinha muitas árvores de bergamota e laranja, limão e a inédita carambola. Conheci essa fruta no sítio dela. Tinha muita fruta, eu ia com um carrinho de mão e ela enchia o carrinho, como eu não iria comer tudo, vendia dez bergamotas por um real na minha rua, por exemplo. Aos quatorze passei a trabalhar na oficina do R., o mesmo que disponibilizou a bombona de água. Nessa altura ele já era meu padrasto. Ali eu lavava peças de veículos, desmontava roda, ajudava a desmontar motores e caixa de câmbio, fazia força pra caramba e vivia fedendo a diesel e gasolina. E tu podia te lavar com o melhor sabão, nunca saia o cheiro e a graxa já estava impregnada nos poros. Trabalhei por dois anos na oficina, ganhava $R \$ 60,00$ por semana. Trabalhava de tarde e de manhã, estudava.

Quando terminei o ensino fundamental, o L. disse que iria para a escola Padre Reus. Então, eu e o W. decidimos que queríamos ir para lá também. A escola na época sorteava o turno e eu fiquei no turno da manhã e meus amigos no turno da tarde. Falta de sorte hein?! A escola Padre Reus era muito diferente da escola SAP, tinha câmera de segurança dentro da escola (não dentro da sala), banheiros sempre limpos, ginásio de 
esportes, infraestrutura bem diferente do que eu estava acostumado. Outra diferença também é que agora eu passei a utilizar ônibus por conta da distância.

No primeiro ano de colégio, eu fiquei em recuperação em onze disciplinas. Só não fiquei em Artes e Educação Física, no final eu passei de ano. Era o que importava na verdade. Passar de ano me dava provas para mostrar pra minha mãe que eu não era burro.

Aos dezesseis anos, decidi que eu queria fazer estágio, queria sair da oficina. Fui procurar um e encontrei o Projeto Pescar do Grupo Dimed - Distribuidora de Medicamentos. Esse projeto era um curso de vendas e atendimento ao público onde eles remuneram os alunos com uma bolsa. Ao final do curso tu tens a opção de trabalhar em uma das farmácias ou dentro do Grupo Dimed mesmo. Ao final do curso tive três propostas e acabei não aceitando. Meu desejo era servir o Exército. Ao realizar o teste no quartel, não passei nos testes físicos para o Centro de Preparação de Oficiais da Reserva (CPOR).

Fui para o segundo ano do ensino médio e as dificuldades no colégio só aumentavam. Nesse meio tempo tivemos que sair daquela meia água (a casa com dois cômodos) e fomos morar na mesma rua, só que em uma casa onde era um estoque de ferramentas. Um lugar muito úmido, sem piso, só um cimento esburacado, telha de zinco. Quando chovia, minha nossa, muita goteira. Enfim, ao menos tinha água encanada. Nessa época fiz meu primeiro gato em luz. Subi num poste daqueles de madeira e com uma escada emendada na outra pra ficar mais alta e fiz um gato de luz. Já estávamos três dias sem luz, e, na minha rua pouca gente pagava luz. A maioria era gato mesmo. A nossa rua se chamava "beco do fio".

Um dia, conversando com um amigo na minha rua, ele ofereceu pra eu fazer uns bicos em uma fábrica de rapaduras. Ficava ali no bairro Cristal, fui lá e o cara gostou dos meus serviços. Fiquei trabalhando lá quase um ano, aprendi a fazer rapadura $e$ paçoquinha. Comecei a comprar dele e revender no colégio, direto para os professores, 
meu apelido virou "Paçoquinha". Eu gostava de trabalhar lá, mas ficar virando tacho de rapadura em pleno verão era terrível. Certo dia, o dono da fábrica queria me contratar com carteira assinada. Para isso eu deveria estudar à noite, não aceitei e fui embora.

No meu último ano de ensino médio não resisti aos provões e rodei em matemática. Decidi que permaneceria no Padre Réus e faria tudo de novo. Minha relação com os professores e direção era muito boa, então no primeiro dia de aula eu pedi para falar com o serviço de orientação educacional da escola e me comprometi em estudar. No terceiro ano eu gostava muito de Biologia. A Geografia em si eu não guardei boas lembranças. Lembro de pintar mapas e sinalizar capitais, não que eu não tenha tido o conteúdo em si, mas não lembro mesmo.

Em 2011, ano que eu viria a me formar no ensino médio, foram sorteadas duas bolsas de estudos para um cursinho Pré-vestibular. Foi nesse ano que eu descobri a existência da famosa Universidade Federal do Rio Grande do Sul (UFRGS). Eu ganhei a bolsa e passei a fazer o cursinho à noite. Nesse meio tempo, uma vizinha da rua estava vendendo uma casa de madeira em um terreno por 10 mil reais. Minha mãe pediu emprestado para uma tia e comprou o terreno. Passamos a morar em uma casa com dois quartos, cozinhalsala e banheiro. Meu irmão foi morar com a então esposa dele em Portão - RS e eu já tinha mais dois irmãos (hahah). Um de 18 anos e outro de 13 anos. Fiz o cursinho por quatro meses e desisti, decidi que eu deveria terminar o ensino médio e fazer o Exame Nacional do Ensino Médio (Enem). Saí do cursinho e arrumei um trabalho em uma cafeteria no bairro Menino Deus. Meu primeiro emprego de carteira assinada,

Em 2012, decidi que iria descansar dos estudos e iria só trabalhar. Minha relação com o trabalho sempre foi mais forte que com o estudo, afinal com trabalho eu poderia ajudar minha mãe. Minha mãe sempre trabalhou de faxineira. Quando minha irmã nasceu, ela decidiu que iria cuidar da filha dela, passou a receber uma pensão por morte do primeiro (e único) marido, o pai do meu irmão mais velho, um salário mínimo. Ela fazia chover com aquele dinheiro. Arrumei um emprego na minha rua, auxiliar de 
serviços gerais em uma fábrica de sacos plásticos. Nessa empresa eu trabalhei, caraca, fazia força pra caramba com as bobinas de meia tonelada de polipropileno. Teve uma semana que eu trabalhei das 7h30 até Oh00 por três dias seguidos. Foi assim que eu consegui tirar minha carteira de motorista. Mas voltando para o trabalho, em 2013 decidi que iria fazer um curso técnico. Não sabia o que fazer. Escolhi o Técnico em Segurança do Trabalho. Foi a partir dele que eu entendi que eu corria risco de vida devido às exposições a agentes nocivos na empresa de sacos. Pedi demissão e depois voltei a trabalhar lá por alguns meses (faltou grana pra pagar o curso).

Ao final do curso técnico, consegui um emprego na instituição onde fiz o curso ténico mesmo, como assistente comercial. Eu vendia cursos técnicos. Aí eu pensei em fazer um cursinho pré-vestibular. Eu precisava entrar na faculdade, não sabia o que iria cursar, mas queria fazer. Falei com minha chefe para trocar de horário, eu queria ter as noites livres porque o cursinho era mais barato à noite, ela não liberou e eu fiz a matrícula igual. Fui transferido de setor e passei a atuar no atendimento ao aluno. Nessa época fui morar na casa de um amigo, o pai dele foi na minha casa e conversou com a minha mãe. Ele morava na Vila Nova, era mais perto do centro e tinha mais linhas de ônibus. Como eu não sabia o que iria cursar, pensei nas coisas que eu mais gostava, pensei na hora em Biologia. Meu objetivo era UFRGS, tenho cota de ensino público e renda, tenho chance, pensei eu. Biologia era só diurno... Ah, então vamos ver... Engenharia Ambiental, somente diurno... O pai do meu melhor amigo é geógrafo e um dia, no jantar, ele falou pra mim: L., dá uma olhada na Geografia, acho que tu vais gostar. Fiz a inscrição para UFRGS em Geografia e pensei comigo, vou fazer licenciatura pra ter uma alternativa de renda.

Passei no meu primeiro vestibular e fui chamado para trabalhar como técnico em segurança do trabalho na empresa que fiz estágio. Muita novidade ao mesmo tempo. Foi uma loucura boa! 
Meu desafio sempre foi voltado para receber um salário melhor, ter condições para dar uma casa para a minha mãe, levar ela para viajar e tudo mais.

Eu ainda acho que fui um privilegiado, tive pessoas na minha vida que me ergueram mesmo. Poderia e tive oportunidades de ter outro destino, talvez nem estivesse vivo para contar história, mas para mim, o principal papel da escola, foi de integralização, foi lá que eu conheci o G., meu melhor amigo e filho de um geógrafo que me apresentou a Geografia de outra forma, foi lá que eu descobri a UFRGS, que encontrei as coisas boas dessa vida."

Quanta estrada tem esse rapaz! Que relato! Conseguimos visualizar várias imagens e passagens. Quantos tem histórias similares - ricas em passagens, mas de vida pobre e não raro sofrida - facilitando assim o estabelecimento de vínculos entre professores/as e alunos/as, ampliando a visão de mundo de todos. Humanizando-nos. Podemos ser educadores/as sem nos envolver com geografias tão diversas? Sim, mas que desperdício!

Acreditamos que aqui cabe fazer menção ao filme "Quem quer ser milionário?" (filme de 2008, dirigido por Danny Boyle) de onde capturamos a frase do título. Quantas crianças com suas infâncias 'roubadas' pelo trabalho infantil? Quantos sonhos de uma vida melhor para seus filhos, pais, familiares? A mesma profissão (a de professor) será vista de forma tão distinta conforme a origem social do aluno. Para um membro de uma classe abastada soaria quase impossível escolher tal carreira, talvez até mais improvável que algum filho de pobre fazer um curso de elite.

É impossível esse relato não motivar nossas reflexões dada sua sensibilidade. Biografias são instrumentos úteis ao propiciar a reflexão sobre a condição de vida de nossos pares. A história sendo grafada no espaço e este possibilitando a reflexão sobre a sociedade que temos. De tal modo, colocamos aqui uma possibilidade de escutar os/as acadêmicos/as e perceber suas trajetórias, sentidos e vivências. 
A formação acontece quando os professores, reunidos em um contexto de formação, dedicam-se - voluntariamente e a partir de questionamentos pessoais de sua experiência e desejos de aprender - a explorar os acontecimentos constitutivos de sua trajetória: que relações posso estabelecer entre minha vida e minha prática profissional? O que eu aprendi, onde e como me formei? Que projetos fiz e como eles mobilizam minhas experiências anteriores? (BOLÍVAR, 2011, p. 14, tradução nossa).

A proposta das narrativas na formação inicial com acadêmicos e acadêmicas busca conhecer os contextos sociais, experiências e desejos desses/as alunos/as. Consideramos que a escuta, por meio da narrativa, fundamental para compreender os projetos deles/as, suas histórias e contextos para, a partir desse ponto de vista, pensar na condução de nossas aulas. Esse momento, conforme percebido nos relatos supracitados e nos que ainda iremos apresentar, são ricos pois expressam sensibilidades e possibilidades, permitindo o/a docente estabelecer relações do ensino com as vivências da turma.

\subsection{Caso quatro}

Saída de campo com os/as acadêmicos/as do sexto semestre da licenciatura... ${ }^{3}$ O verão se aproxima e, para ajudar, o destino da turma era o município de Foz do Iguaçu-PR - conhecido pelo seu calor continental dessa estação. A proposta, para além de visitas a educandários, era conhecer a Usina Binacional de Itaipu (famosa por ser uma das maiores geradoras de energia do mundo) e o Parque Nacional do Iguaçu, no qual ficam localizadas as Cataratas, destino turístico mundial. Como a turma em questão é do período noturno e, portanto, grande parte do grupo trabalha, a alternativa foi realizar a atividade em um final de semana. Após uma manhã longa e cansativa, paramos em um simples restaurante nas proximidades da Ponte Internacional da Amizade (que liga o Brasil ao Paraguai). O calor escaldante não abatia o grupo que havia dormido uma noite

30 relato deste caso é narrado por Marcos Bohrer. 
em uma simples hospedagem e, mais uma vez, iria virar a madrugada no ônibus, retornando para a cidade na qual estudavam.

Parado em uma pequena sombra, conversando com a outra professora responsável pela atividade de campo, aproxima-se uma acadêmica e relata "Nossa, professores, eu queria que esse final de semana não acabasse nunca... foi o melhor final de semana da minha vida". Por se tratar de uma estudante tímida, questiono qual foi o lugar mais longe que ela já foi e ela continua a falar: "Foi nessa viagem, aqui para Foz. Nós não viajamos para além de locais próximos de casa". Ao ser questionada sobre o que havia mais gostado na viagem, ela complementa "Gostei de tudo: das escolas, usinas, cataratas... tudo perfeito! Se um dia eu for professora, vou querer viajar bastante". Minha colega docente a incentiva a acadêmica a continuar nos estudos, mesmo sabendo que a rotina diária de trabalho, casa, família e estudos não é fácil. Conta de sua experiência enquanto estudante e trabalhadora que, ainda nessa época, tinha uma filha pequena.

Vejamos, no cenário brasileiro, o salário mínimo gira em torno de mil reais ( $R \$ 1.045$ em fevereiro de 2020) e, segundo o Instituto Brasileiro de Geografia e Estatística (IBGE), a renda domiciliar per capita é de $R \$ 1.438$, tendo uma evolução mínima no último ano. Isto é, a renda média de um cidadão/ã de aproximadamente mil e quinhentos reais em uma jornada de trabalho, muitas vezes, para além das 40h semanais, sendo essa a realidade de muitos/as trabalhadores/as. De tal modo, o que se apresenta aqui é um retrato da renda brasileira com base em dados de 2019 e 2020. A situação nos próximos anos pode estar melhor (seria possível?!) ou pior. Isso apenas saberemos no futuro. Para mais, ainda é possível atentar para outros fatos marcantes e duros de nossa realidade (e bem frisado pela Pesquisa Nacional por Amostra de Domicílios (PNADA) do IBGE): a desigualdade de renda entre a população branca, parda e preta e o abismo na remuneração entre gêneros que perdura entre homens e mulheres quando falamos de renda básica 4 . 
Mas o que essa relação de renda média tem a ver com formação de professores e professoras? Olhamos para o quadro de remuneração do Magistério Público Estadual do RS apresentado no Caso 2 - que como já exposto não chega respeitar o piso nacional - e compararmos com a renda média do brasileiro, estamos falando que, sim, mesmo em um cenário precário, ser professor/a pode significar uma ascensão social. Essa remuneração pode, em muitos casos, representar uma vida digna e isso reflete na vida de nossos/as estudantes que desejam se tornar professores(as).

Dentro desta lógica, perguntei para a acadêmica por qual motivo escolheu uma licenciatura. Ela, mesmo sem saber ao certo, respondeu-me: "Sempre queria estudar, né, sor, ter uma faculdade e poder ganhar melhor. Já trabalho na escola... e como o campus aqui perto tinha o curso a noite, achei que seria uma boa oportunidade". Observo que o sonho não é exatamente ser professora ou trabalhar com a formação de crianças e/ou jovens. Não é desenvolver conhecimento acerca de uma ciência e, a partir dela, refletir sobre o mundo e a condição humana... as motivações estão em momentos, lugares e oportunidades.

\subsection{Caso cinco}

Fui barbeiro, e li livros, como deviam ler todas as pessoas para ultrapassarem a condição pequenina do cotidiano e das rotinas. (MÃE, 2018, p. 125)

Como último relato trazemos um licenciado (formado em 2009). Houve pequenos ajustes/cortes, sem modificar sentidos. Vejamos:

Com 32-33 anos ouvi a minha mãe dizer que eu fui uma criança "apagada". Os adjetivos sempre são as partes mais controversas e difíceis de escolher das

https://agenciabrasil.ebc.com.br/economia/noticia/2020-02/brasil-registra-renda-domiciliar-capita-de-r1438-em-2019 e https://agenciadenoticias.ibge.gov.br/agencia-sala-de-imprensa/2013-agencia-denoticias/releases/27594-pnad-continua-2019-rendimento-do-1-que-ganha-mais-equivale-a-33-7-vezeso-da-metade-da-populacao-que-ganha-menos. Acesso em: 10 out. 2020 
frases. Acho que ela foi bem nessa qualificação da criança que eu fui. Sou filho/neto de uma família abastada. Me doíam as grosserias de outras crianças, de amigos, palavras duras de adultos, as demoras a ser escolhido para o time do futebol, enfim, todas essas situações comuns da vida em sociedade. Hoje vejo que fui uma criança sensivel demais e que o choque com o mundo (mesmo que um mundo confortável) me desorganizava.

Tenho lembranças maravilhosas de ir todos os fins-de-semana e férias para a fazenda dos meus avós em XX/RS e de convívio com os muitos primos que tenho. Meu pai era brincalhão e duro comigo, minha mãe era fonte de amor e compreensão. Muitos tios e primos me faziam companhia e embelezavam os natais e páscoas épocas mais esperadas do ano.

Minha mãe era professora do Estado, lecionava História e Estudos Sociais. Meu pai era bancário da falecida Caixa Econômica Estadual. Minha trajetória escolar nunca foi muito fácil, principalmente para a minha mãe, que constantemente era chamada no Colégio para ouvir que eu era um guri de bom trato, mas que não tinha interesse nos estudos e que aprendia muito pouco. E não era mentira.

Fiz até a $\sigma^{a}$ série no $B C$, um enorme Colégio de freiras aqui em Porto. Para se ter uma ideia do "enorme", cheguei a ser da turma "I" na $4^{a}$ série. Ao final da $6^{a}$ série a minha mãe achou que eu deveria estudar numa Escola na qual eu não fosse só um número, um lugar onde eu tivesse um acompanhamento um pouco mais próximo. Nisso, me mudei para uma pequena Escola de bairro perto da minha casa, comecei a ir a pé (fonte de prazer e autonomia) e logo me adaptei às amizades novas. Estudar, se interessar por algo e passar de ano sem ser raspando não aconteceu até terminar o ensino médio. Mas nessa época eu era atleta (remo) e por ser um guri tranquilo, e graças ao olhar do Colégio (Privado, de classe média alta), terminei o Colégio me sentindo em casa. Posso dizer que fui um adolescente saudável e feliz com amigos e namoros. 
Ao final dessa etapa a minha ideia de mundo profissional era trabalhar com algo que não fosse um escritório. Tive duas experiências como office boy em escritórios de parentes e ali descobri o desgosto por horário comercial e rotinas de trabalho ligadas ao computador. O convívio com o Lago Guaíba nos 4 anos de remo também me ajudou a ver e desenvolver o gosto pela natureza. A minha ideia era ser jornalista, oceanógrafo ou geógrafo. Um bom professor de Geografia no ensino médio me fez ver que poderia ser bem divertido ser professor, pois visivelmente ele se divertia dando aula e nos ensinava coisas que me interessavam. Após um ano de cursinho consegui uma vaga na Geografia da UFRGS, uma realização cognitiva sem paralelo na minha vida até então. Ouvi de ex-colegas e até de um tio que estavam impressionados, pois achavam que eu era burro.

A minha grande motivação para passar na UFRGS era um fato bem claro para mim: eu não queria mais fazer parte daquele mundo playboy de festas e pessoas ricas de onde eu vim. Eu tinha entrado em contato com uns caras que me apresentaram "As Veias Abertas da América Latina" e ouvido falar da possibilidade de um mundo de pessoas mais legais, mais verdadeiras, menos fúteis - que era a UFRGS - e minha meta era conseguir ser desse mundo. A Pontifícia Universidade Católica do Rio Grande do Sul (PUCRS) significava não só boleto para a minha Velha, como também seguir encontrando a playboyzada dos colégios particulares.

Ao me matricular na Geografia, sem saber nada sobre, precisei escolher a ênfase: bacharel ou licenciado? Lembrei das palavras da minha mãe sobre a dificuldade de ser professora e optei pelo bacharelado. Após um semestre, vi que eu queria cursar as cadeiras da licenciatura e troquei a ênfase, mesmo tendo sido repreendido. Do ponto de vista cognitivo, fiz uma faculdade sem grandes luzes. O que eu queria mesmo era tomar cerveja com a galera e fazer amigos. Do ponto de vista das experiências, a faculdade foi muito importante para mim. A minha mãe bancava ônibus, Restaurante Universitário (RU) e xerox. Para o lazer e as farras eu usava a minha bolsa. Com as 
saídas de campo e outras viagens, conheci várias regiões do Rio Grande do Sul, mas principalmente conheci pessoas diferentes de mim durante o curso.

O grande estalo que tive no curso foi no $9^{\circ}$ semestre: na primeira aula de Prática de Ensino. O tal do professor falava coisas que batiam direto com as que eu pensava. Era a mesma forma de pensar que volta e meia eu tinha e que gostava muito, então ouvia dele um pouco do que eu queria ser. Quando comecei o estágio em uma $6^{a}$ série de uma Escola Estadual perto da minha casa, apesar do caos da sala, vi que eu gostava bastante daquilo ali. Esses encontros foram muito poderosos para mim e me deram um certo rumo pós-formatura.

Recém-formado fui ganhar um pouco de dinheiro trabalhando como Recenseador do Censo de 2010, mas a experiência foi desagradável, pois via de regra eu era mal recebido nos lares do bairro burguês e velho que me tocou recensear. Sorte que em seguida me ligaram de uma rede de Escolas de uma igreja para eu ir fazer uma entrevista. Eu não sabia nem assinar um caderno de chamada, mas era a ocasião perfeita para eu começar. Nisso, fui chamado em um renomado cursinho prévestibular por pura afinidade com um dos sócios - aquele professor de Geografia do meu ensino médio. Mesmo que a ideia de saber o conteúdo para o vestibular me assustasse muito, sabia que tinha que encarar o medo, e a vaga era para plantonista de dúvidas, então eu poderia ir pegando conteúdo aos poucos. Terminei o ano com 2 empregos e com a grana eu fui de carro com a namorada da época até o Chile. Cruzar os Andes foi uma experiência muito marcante. Poder ter o meu dinheiro era ótimo.

Comecei o ano seguinte já contratado numa escola maior e melhor, terminei esse ano contratado numa outra escola ainda. Tudo isso porque a vitrine do cursinho era enorme, então as oportunidades em colégios particulares sempre me caíram no colo. A questão é que esse (2012) era meu primeiro ano letivo inteiro, estava em duas Escolas e no cursinho, então a carga-horária extensa e a necessidade de preparação de aulas e correções me massacraram. Quando terminou o ano letivo eu estava esgotado e vi que não queria essa carga de trabalho para a minha vida. Me diziam que 
"acostuma", mas eu não queria me acostumar àquilo. Me demiti dos colégios em janeiro, esperei para me demitir do cursinho em abril, e minha ideia era ser professor de futebol em colônias de férias na Europa. Até que o ano letivo começou, a viagem não saiu do papel, voltei ao cursinho, um outro cursinho menor me chamou e quando vi eu estava levando uma vida mais leve, longe dos Colégios. Seguia dando aula e ganhando alguma grana, coisas que eram importantes para mim. Dois anos só em cursinhos me deram confiança no que eu sabia de Geografia, e mais uma vez uma Escola particular bateu à minha porta e eu aceitei. Só $3^{\circ}$ ano, tudo voltado para o vestibular, então era tranquilo para mim. Me adaptei, gostei, fui bem. Tudo certo. A vida voltou para o trilho dos Colégios e ministro aulas nessa instituição desde 2014. Já dei aulas em Canoas, Montenegro e Santa Cruz do Sul, mas hoje demoro entre 5-15 minutos para chegar nos trabalhos, o que é um privilégio enorme.

Em 2019 comecei a dar aula no Colégio que me formei e isso é muito significativo para mim. Aos poucos fui perdendo o gosto pelos vestibulares e pelo ENEM e isso me levou ao mundo das avaliações por habilidades. Fiz uma especialização em psicanálise da infância e adolescência e isso me ensinou a olhar os sujeitos como únicos. Também pude fazer um mestrado em Ensino de Geografia e aprofundar um pouco os meus estudos e compreensões sobre o meu papel e objetivos como educador. Me demiti do cursinho que me abriu tantas portas e hoje sou extremamente feliz como educador escolar. Tenho o privilégio de ganhar um salário ótimo e dou algo em torno de 30h/a semanais. Minha relação com as turmas é motivo de completude para mim, e meu maior objetivo como professor é demonstrar o encantamento que tenho com o conhecimento, pois acho que isso pode motivá-los a correr atrás dos conhecimentos que os encantem.

Gostaria de dizer que me sinto um bom professor e é muito bom me sentir competente e importante para meus alunos, pois trabalhar com educação é extremamente difícil - e não é para qualquer pessoa - eu que o diga. Nessa quarentena que ainda vivo (fez 6 meses que dou aulas em casa), me dei conta esses dias que várias 
vezes as horas de aula, mesmo que cansativas, são momentos também de prazer para mim. Não sei o que o futuro me reserva, não me esqueci dos desassossegos profissionais que atravessei, mas reconheço que esse meu aquilagora docente é fonte de alegria e satisfação".

Recebi este texto muito rapidamente após solicitá-lo. Sua leitura flui já que a escrita é límpida. Fica evidente que teve uma trajetória bem menos atribulada do que o colega do caso 3. O leitor certamente fará suas reflexões com os detalhes que Ihe chamam a atenção. É alvissareiro que há aqui, claramente, a sensação de bem estar (felicidade) no exercício da docência. Certamente que a opção de trabalhar numa carga horária digna, além do salário, faz dele um caso a ser desejado. Condições de trabalho e boa remuneração não garantem felicidade, mas ajudam muito, não há dúvida. Porém, esse contexto transparece em raras ocasiões quando lidamos com a docência.

A pressão crescente da prestação de contas ameaça erradicar aquele amor e interesse pelo mundo (o amor pela causa como a causa) e pelos alunos. O risco: um professor que já não partilha o mundo com os jovens e já não pode mais cuidar de si mesmo, ou seja, um professor que deixa, absolutamente, de ser um professor. (MASSCHELEIN; SIMONS, 2014, p. 94)

Masschelein e Simons (2014) reforçam essa hipótese, ao apontar que uma profissão voltada à cobrança por uma pretensa qualidade e uma responsabilização constante por resultados retiram, aos poucos, o caráter pedagógico da profissão. Alicerçando isso às condições precárias e a sobrecarga de trabalho sabidas e mencionadas, sobra uma preocupação e um estresse constante com as condições de trabalho e falta tempo para o principal, afinal: o ato de professorar. 


\section{A ESCOLHA PROFISSIONAL E OS CAMINHOS DA DOCÊNCIA}

Ao considerar esses cinco casos, surge uma pergunta: existe alguma relação direta entre as escolhas? Antes de tudo, é importante refletirmos que muito daquilo que fizemos não é tão consciente ou racional.

De qualquer forma aqui gostaria de reiterar que muitas decisões centrais de nossa vida (carreira e relações afetivas) não raro são pouco... racionais. Não por acaso no início destas linhas falo no inconsciente e de como é recente a "consciência" de que ele é de suma importância na condução - sem que nós sejamos timoneiros - de nossa vida. Para resumir: sim, eu escolhi ser professor, ainda que de forma não muito estudada (consciente?) ou dialogada, pois pouco conversei sobre esta decisão, inclusive com amigos e familiares. $E$, tendo o privilégio (ou a sorte?) de exercer a docência desde os primeiros semestres do curso (por minha iniciativa, sim), jamais me arrependi desta escolha. (KAERCHER, 2020, p. 632)

Nos cinco relatos, a escolha pela docência não está revelada como algo pontual, consciente e de uma oportunidade. Ninguém quer, no fundo, ser um milionário. O que se quer é uma vida digna: poder trabalhar $30 \mathrm{~h}$ e usufruir de qualidade de vida; viajar com a família em algum final de semana; ter uma casa para viver com sua mãe. Ou seja, nada muito distante ou pretencioso. E por qual motivos chegamos na docência?

Na maioria dos casos, não temos respostas. É, como pontuado na citação acima e visto nos relatos que trazemos, uma decisão tão significativa para nossas vidas e, ao mesmo tempo, muito despretensiosa (ou seria inconsequente?). Pode ser um pai de um amigo, um jantar, uma opção posta pela oferta do curso perto de nossa residência, um escape do que esperam de nós, qualquer coisa. Mas, mesmo sem sabermos ao certo o que nos leva a sala de aula, encontramos na docência uma fuga ou um encontro do que nem bem ao certo sabemos.

Através da metodologia utilizada, com relatos autobiográficos e narrativas de vida, é possível identificar-se e, até mesmo, perceber-se dentro das passagens. Escutar sujeitos é, para nós, parte fundamental do processo de formação de 
professores, uma vez que ao narrar sua trajetória permite ao sujeito identificar o que foi significativo para chegar na sua atual etapa da vida. Ao mesmo tempo, ao escutar e relatar essas trajetórias, difundimos elementos fundamentais para a formação de atuais e futuros professores. Isso posto, para além de um exercício de autoformação, as narrativas servem para desvendar elementos que atravessam (no nosso caso) a vida e a formação de atuais e futuros professores.

As vidas e trajetórias profissionais dos professores e professoras, como narrativas de ação, devem ser pautadas em uma "genealogia do contexto" que lhes dote de um sentido mais amplo e, ao mesmo tempo, conceda toda a relevância ao dizem e sentem. Como já analisado em outro momento, se os relatos que os professores fazem são sempre singulares, localizados em um espaço e tempo; devem ser, antes de mais nada, complementados ou "triangulados" com outras narrativas do mesmo sujeito, em espaços e tempos ampliados; e com outros meios (documentos e depoimentos, por exemplo) que ajudem a compreender o contexto nos quais ganham um sentido mais amplo. Relatos (auto)biográficas sim, mas também um trabalho de elaboração biográfico e dialógico. (BOLÍVAR; SEGÓVIA, 2018, p. 808-809, tradução nossa)

Esse tipo de escuta e análise permite encontrar elementos dentro de um sistema social vivido, o qual permite dialogar com as singularidades de cada sujeito. Tal como Bolívar aponta: o sistema social para compreender um fenômeno docente torna-se uma importante ferramenta para trabalharmos a formação inicial e continuada de professores. Isto é, refletir sobre o que se faz, como se fez e o que me trouxe até aqui é o primeiro passo para a autoformação.

Assim, a escuta das trajetórias formativas e seus momentos significativos são primordiais para ir além de um modelo mais objetivo de pesquisa, trazendo dimensões subjetivas presentes no ser e tornar-se professor. A singularidade tempo-espaço é um elemento próprio das narrativas, permitindo encontros entre experiências pessoais e profissionais com elementos espaciais e temporais comuns a inúmeros sujeitos. Ao trazermos, neste texto, memórias cotidianas de professores e alunos, buscamos elencar elementos particulares (do eu) e coletivos 
(espaço social no qual vivemos) e refletir sobre de que maneiras eles podem se articular e contribuir para a reflexão sobre a atuação e formação de professores.

Uma narrativa é mais que um conjunto de afirmações, uma vez que ela constrói - em seu lugar - um mundo. Sua "verdade" é o resultado de uma produção textual - e não poderia ser menos que isso. Por isso, uma (auto)biografia ou história de vida nunca é um registro do que aconteceu, mas uma interpretação (variável no tempo) da nossa experiência. Como na literatura, com os mesmos fatos o sujeito pode traçar e elaborar diferentes enredos. (BOLÍVAR, 2012, p. 23, tradução nossa)

Ao narrar, estamos propondo não apenas uma simples escuta dos nossos alunos e alunas. Estamos possibilitando a construção de uma autorreflexão sobre o que os trouxe até aqui. E, a partir disso, que caminhos eles pretendem trilhar. $E$ você, leitor/leitora, quais são suas satisfações, motivações e perspectivas? Esse simples (no sentido prático) porém muito complexo (e existencial) questionamento é o que propomos, enquanto docentes formadores de professores e professoras, realizar em sala de aula.

Retornando aos casos 01 e 02, a preocupação desses acadêmicos que, mesmo em momentos distintos - um está terminando a graduação e o outro iniciando o curso - volta-se não a remuneração propriamente dita, mas uma condição de vida digna. Ou seja, o que me trouxe até aqui? Para onde vou depois daqui? Como destacado por Bolívar, os discentes estão interpretando sua história e, para além disso, projetando-a.

Se algo deve ser dito desses nossos diferentes "casos" relatados é que nós, docentes, formadores/as de professoras e professores, devemos escutar os/as acadêmicos/as. Para compreender o universo no qual eles/elas e nós estamos inseridos. Pergunte quem são eles/elas. É bom. Faz bem. Para nós e para eles.

O que quero destacar, sobretudo aos jovens que me leem, é que a escola e o professor têm sim, ainda e por muitos anos, uma enorme variedade de "utilidades", "necessidades" e possibilidades. Sim, a escola e um bom professor são precisos, ainda que a vida não seja precisa. Justamente pelas imprecisões, indecisões e incertezas que a vida tem, nós continuaremos a ser necessário (precisos). E a busca dessas 
possibilidades e necessidades você não encontrará apenas em manuais técnicos ou aulas da universidade. São projetos de vida que se constroem no estudo e na caminhada com nossos pares e alunos. (KAERCHER, 2020, p. 638)

Então é isso: a escola e nós, professores e professoras somos e seremos necessários. Isso, por si só, não basta. O que colocamos é justamente as possibilidades e os projetos que essa caminhada nos possibilita. Chegamos como e saímos de que forma dessa formação? Quem é o João, a Gabriela (hipotéticos estudantes) quando chegaram na minha aula de graduação? Uma crença, sobretudo, nas classes populares. O estudo como (única?) chance de se ter uma vida menos "lascada". Mito ou realidade? Os dois. O estudo não garante futuro melhor (as condições de partida de cada um ficam muito evidentes e são muito diferentes). Ao mesmo tempo - tudo é e não é, já diria Guimarães Rosa no Grande Sertão: Veredas - há pilhas de relatos de gente que, através do estudo, conseguiu uma vida mais digna. Boa discussão para se ter na sala de aula.

Incomoda-nos ouvir, em 2020, um jovem dizer que tinha "vergonha de perguntar" em aula! Parece coisa do século XIX! Quem de nós já não ouviu falar que a curiosidade e a imaginação são inerentes às crianças? Como a escola (e nós, professores) podemos cercear essa curiosidade? O que ganhamos diante de alunos que temem o professor? A educação tem dificuldade de compreender o benefício da liberdade de expressão.

Algo que nos chama a atenção são as aulas de Geografia em si. Muitas vezes não deixam boas lembranças. Pintar mapas e sinalizar capitais... Ouvimos de estudantes: "não que eu não tenha tido o conteúdo em si, mas não lembro mesmo". Temos muito a avançar, mas aqui não é hora de fazer denúncias ou promessas. Também poderíamos destacar: um desde cedo sonhava em ser geógrafo/oceanógrafo, enquanto outro apenas ouvirá falar universidade depois de ter passado por múltiplos empregos. 
Parece-nos que tais relatos, ao serem compartilhados com alunos da educação básica, estimulam vínculos. Isso é docenciar, isso é se existenciar. Isso é o professor colocar-se na relação com os alunos.

\section{CONSIDERAÇÕES FINAIS}

A ditadura é que foi uma terrível máquina de roubar a metafísica aos homens. (MÃE, 2018, p. 191)

Mesmo sem a pretensão de chegar a alguma tese primorosa, temos várias possíveis ideias/conclusões que servem para os professores pensarem sua docência, e, via a geograficidade de nossa existência, proporem a percepção das múltiplas realidades e existências dos grupos com os quais lidamos ou estudamos.

A $1^{\text {a }}$ delas faz ode à democracia. Frágil, imperfeita e em permanente crise. Bendita liberdade de expressão e criação. Toda ditadura, ainda que ofereça seu canto de sereia de "paz" e "progresso" material, jamais se justifica. Gerações mais novas cuidem com o risco das soluções de força. Os problemas da sociedade são complexos e soluções rápidas são ficção. O custo é altíssimo quando a liberdade é cerceada. Entendamos "metafísica" aqui como o direito do ser humano não se contentar apenas com pão e água; um teto e roupa. Educar exige o estímulo ao contraditório, ao plural, mesmo que este envolva conflitos. A vida apresenta conflitos. A escola é uma ágora para a busca do convívio democrático; lugar para acolhida do diverso que habita o mundo. E a educação precisa de recursos financeiros. Não sai barato.

As questões éticas e existenciais vivem na escola. E a ela dão vida. Os professores, não raro, são procurados para ouvirem desabafos de jovens imersos nas mais variadas questões existenciais. Resistir ao aconselhamento é um alerta. Não por omitirmos nossa opinião, afinal, opinião todos temos, mas para ouvir atentamente (o que é de suma importância). Antes de dizer faça isto ou aquilo, sugerimos fazer perguntas para que o jovem amplie seu campo de visão, veja 
outras facetas da questão. De qualquer forma fica evidente que ser professor - de Geografia ou qualquer outra disciplina - é muito mais do que saber Geografia. A profissão não é apenas uma questão "técnica". Não somos "fabricadores de mentes alheias", mas sentimos que uma beleza (e abismo) da profissão é lidar com mentes jovens em ebulição.

E a que conclusão "pedagógica" (didática) isso nos leva? Peçam que seus alunos, seja lá quais forem suas idades, falem de sua existência, pois esta, ao ser relatada, evidencia também a nossa existência no espaço. Os lugares ganham cores e sabores (e dores) e isto é muito bonito, muito educativo. A escola e a universidade permitem essa liberdade ou devem atender o currículo/conteúdos propostos nas ementas? Para saber mais, fica o "resultado" do nosso "artigo", em forma de pergunta para o leitor/a: e você, já escutou o seu/sua aluno/a hoje?!

Mais do que ensinar Geografia (ou Matemática, ou Filosofia) a escola é um processo civilizatório onde o direito a expressar-se deveria ser tão sagrado quanto o dever de respeitarmos os que não compartilham o nosso mundo simbólico. Direito e dever, pode parecer careta, mas a educação prepara-nos para a convivência respeitosa. Ou beiramos a barbárie. Isso pode ser evidenciado quando as classes mais pobres são tidas, inclusive por si mesmas, como 'insuficientes', portanto, sujeitas a serem tratadas com menos respeito. Uma cidadania rebaixada. A família e escola reforçam a baixa estima dos que tem menos posses. Sem soluções fáceis, finalizamos com Silva:

Ser professor de ensino fundamental e médio exige um grande amor por uma atividade cantada em prosa e verso, louvada em discursos políticos, especialmente em época de campanha eleitoral, mas desvalorizada na hora da verdade: o contracheque. Oito estados não pagam o piso fixado em norma federal. (...) Somos certamente um dos países a entregar um dos piores serviços pelos impostos recebidos e a mal remunerar os professores de quem se espera a construção do futuro dos nossos filhos e netos. Paga-se pouco, cobra-se muito e espera-se tudo. (SILVA, 2020b, grifo nosso)

Você quer ser milionário? Respostas variadas. Você que ser professor? Sim, mas quero ser feliz sendo professor/a. Tendo escolhido esta carreira não quero ser expulso dela por 
impossibilidade de manter-me com dignidade numa sociedade que trata tão mal (financeira e simbolicamente) esta carreira. Se queremos um país mais democrático, justo e inclusivo, os educadores precisam ser melhor tratados de forma prática. Optamos por encerrar com uma frase impactante e importante, que queremos ouvir muitas vezes: "sou extremamente feliz como educador". Hosana!

\section{REFERÊNCIAS}

AMORIM, M. A.; SALEJ, A. P.; BARREIROS, B. B. C. B. "Superdesignação" de Professores na Rede Estadual de Ensino de Minas Gerais. Revista Brasileira de Educação, v. 23, p. 1-22, 2018.

BOLÍVAR, A. Dimensiones epistemológicas y metodológicas de la investigación (auto)biográfica. In:ABRAHÃO, M. H. M.; PASSEGGI, M. da C.. Dimensões epistemológicas e metodológicas da pesquisa (auto)biográfica: Tomo I. Natal: EDUFRN, 2012, p. 27-69.

BOLÍVAR, A. O esforço reflexivo de fazer da vida uma história. Revista Pátio, n. 43, p. 12-15, ago, 2011.

BOLÍVAR, A.; SEGOVIA, J. D. La investigación (auto)biográfica y narrativa en España: principales ambitos de desarrollo en educación. Revista Brasileira de Pesquisa (Auto)biográfica, v. 3, n. 9, p. 796-813, 20 dez. 2018.

KAERCHER, N. A. As Passadas no Deserto do Camelo Vazio Sem Destino. In: REGO, N.; KOZEL, S. Narrativas, Geografias e Cartografias: para viver é preciso espaço e tempo. Porto Alegre: Compasso Lugar Cultura, 2020.

MÃE, V. H. A máquina de fazer espanhóis. 20ª edição. Porto (Portugal): Porto Editora, 2018.

MASSCHELEIN, J.; SIMONS, M. Em defesa da escola: uma questão pública. 2 ed. Belo Horizonte: Autêntica, 2014.

SILVA, J. M. da. Meu coração bate pelos vulneráveis. Correio do Povo, Porto Alegre, ago. 2020a. Disponível em: Www.correiodopovo.com.br/blogs/juremirmachado/meucora\%C3\%A7\%C3\%A3o-bate-pelos-vulner\%C3\%A1 veis-1.475394. Acesso em: 29 out. 2020.

SILVA, J. Machado da. Pouco, muito, tudo. Correio do Povo, Porto Alegre, ago. 2020b. Disponível em: www.correiodopovo.com.br/blogs/juremirmachado/pouco-muito-tudo1.480746. Acesso em: 29 out. 2020. 


\section{1 - Nestor André Kaercher:}

Doutor em Geografia e docente na Faculdade de Educação (FACED) da Universidade Federal do Rio Grande do Sul (UFRGS) e no Programa de Pós-Graduação em Geografia da UFRGS.

https://orcid.org/0000-0003-4005-3134 - nestorandrek@gmail.com

Contribuição: Redação e elaboração do manuscrito, coleta e análise de dados, participação e análise da discussão dos resultados, revisão e aprovação da versão final do artigo.

\section{2 - Marcos Bohrer:}

Professor do Instituto Federal de Educação, Ciência e Tecnologia Catarinense (IFC). Doutorando na linha de Ensino de Geografia no Programa de Pós-Graduação em Geografia da Universidade Federal do Rio Grande do Sul.

https://orcid.org/0000-0001-9817-9333 - marcosrbohrer@gmail.com Contribuição: Redação e elaboração do manuscrito, coleta e análise de dados, participação e análise da discussão dos resultados, revisão e aprovação da versão final do artigo.

\section{3 - Igor Armindo Rockenbach:}

Doutorando na linha de Ensino de Geografia no Programa de Pós-Graduação em Geografia da Universidade Federal do Rio Grande do Sul (UFRGS). Mestre em Geografia (2017) e Licenciado em Geografia (2015) pela Universidade Federal de Pelotas (UFPel).

https://orcid.org/0000-0002-2039-2369 - irockenbach@outlook.com

Contribuição: Redação e elaboração do manuscrito, coleta e análise de dados, participação e análise da discussão dos resultados, revisão e aprovação da versão final do artigo.

\section{Como citar este artigo}

BOVO, M. C.; BRAGA, P. J. L. Perspectivas da funcionalidade das praças da pequena cidade de Juranda-PR, Brasil. Geografia Ensino \& Pesquisa, Santa Maria, v. 25, e41, p. 1-29, 2021. DOI 10.5902/2236499462953. Disponível em: https://doi.org/10.5902/2236499453300. Acesso em: dia mês abreviado. ano. 